\title{
Pancasila Values as Strengthening Character Building during the Covid -19 Pandemic
}

\author{
Leo Agung S. \\ Pusat Studi Pengamalan Pancasila (PSPP) \\ leoagung@staff.uns.ac.id
}

\section{Article History}

accepted 24/03/2021

approved 10/04/2021

published 20/04/2021

\begin{abstract}
Pancasila values as the noble values of the Indonesian nation have existed since our ancestors. The divine precepts are related to animism and dynamism, which continued to develop during the Hindu Buddhist and Islamic kingdoms until now. During the Majapahit Empire, the religious values of Pancasila were strengthened by the existence of two Hindu-Buddhist kingdoms that lived peacefully side by side. The value of unity and oneness is explicitly written by Mpu Tantular in the Sotosoma Book, namely Bhinneka Tungal Ika. Furthermore, when Bung Karno on June 1 issued five principles as the basis for the state he would form, which was named Pancasila, and finally on August 18, 1945, Pancasila was established as the State Foundation. After this state is formed, it is necessary to have a character building so that every citizen has a sense of love for the nation and homeland. That is why it is necessary to develop character that is rooted in the values of Pancasila, namely religious values, compassion, self-control, cooperation, mutual respect / respect, responsibility, and persistence in handling Covid-19. Thus the values of Pancasila reinforce character building.
\end{abstract}

Keywords: Pancasila values, reinforcement, character buliding, Covid -19

\begin{abstract}
Abstrak
Abstrak dalam bahasa Indonesia mengikuti kaidah dalam Pedoman Umum Ejaan Bahasa NilaiNilai Pancasila sebagai nilai luhur bangsa Indonesia sudah ada sejak nenek moyang kita. Sila Ketuhanan terkait dengan kepercayaan animisme dan dinamisme, yang terus berkembang pada masa Kerajaan-kerajaan Hindu Budha dan Islam hingga sekarang. Masa Kerajaan Majapahit nilai-nilai religiuas Pancasila diperkuat dengan adanya dua agama kerajaan Hindu Budha yang hidup berdampinagn secara damai. Adapun nilai persatuan dan kesatuan secara tegas dituliskan oleh Mpu Tantular dalam Kitab Sotosoma, yakni Bhinneka Tungal Ika. Lebih lanjut, ketika Bung Karno pada tanggal 1 Juni mencetuskan lima asas sebagai dasar negara yang akan dibentuknya, yang diberi nama Pancasila, dan akhirnya pada tanggal 18 Agustus 1945 Pancasila ditetapkan sebagai Dasar Negara. Setelah negara ini terbentuk, maka perlu character building agar setiap warga negara memiliki rasa cinta bangsa dan tanah air. Itulah sebabnya diperlukan pembangunan karakter yang berakar pada nilia-nilai Pancasila, yakni nilai religius, kasih sayang, pengendalian diri, kerjasama, saling menghargai/menghormati, tanggung jawab, dan ketekunan dalam menangani Covid-19. Dengan demikian nilai-nilai Pancasila menjadi penguat character building.
\end{abstract}

Kata kunci : nilai-nilai Pancasila, penguat, character buliding, Covid -19

Social, Humanities, and Education Studies (SHEs): Conference Series https://jurnal.uns.ac.id/shes

p-ISSN 2620-9284

e-ISSN 2620-9292 


\section{PENDAHULUAN}

Dewasa ini dalam kehidupan bermasyarakat, berbangsa dan bernegara telah menunjukkan adanya degradasi dalam pembentukan karakter bangsa Indonesia. Degradasi nilai-nilai dan moral sebagai inti atau core values dari pembentukan karakter tidak saja terjadi di kalangan masyarakat awam, tetapi juga telah merambah ke tokoh masyarakat, para pelajar, para pendidikan, para seniman, artis dan bahkan elit politik. Sebagai contoh masih maraknya masalah narkoba, pertentangan antar kelompok masyarakat, pertikaian antar pelajar, geng motor dan bahkan korupsi . Jika pembudayaan nilai-nilai menyimpang tersebut pada dasarnya adalah hasil proses pendidikan di negara kita ini dalam waktu yang lama sehingga melahirkan generasi masyarakat yang kurang berkarakter. Disinyalir proses pendidikan formal di sekolah kita baru berhasil memindahkan pengetahuan peserta didik (transfer of knowledge) ketimbang pemindahan nilai (transfer of value).

Bila diperhatikan dengan cermat, konstitusi Indonesia telah mengamanatkan pentingnya pendidikan karakter, seperti bunyi pasal 31 ayat 3 yaitu "Pemerintah mengusahakan dan menyelenggarakan satu sistem pendidikan nasional yang meningkatkan keimanan dan ketakwaan serta akhlak mulia dalam rangka mencerdaskan kehidupan bangsa yang diatur dengan undang-undang" (Ditjen Dikdasmen Depdiknas, 2003). Untuk menjalankan amanah itu, UU No. 20 tahun 2003 tentang Sistem Pendidikan Nasional menetapkan fungsi dan tujuan pendidikan nasional yaitu mengembangkan kemampuan dan membentuk watak serta peradaban bangsa yang bermartabat dalam rangka mencerdaskan kehidupan bangsa dan berkembangnya potensi peserta didik agar menjadi manusia yang beriman dan bertakwa kepada Tuhan Yang Maha Esa, berakhlak mulia, sehat, berilmu, cakap, kreatif, mandiri, dan menjadi warganegara yang demokratis dan bertanggung jawab. Salah satu pilar yang harus menjalankan pendidikan karakter adalah perguruan tinggi (Ditjen Dikdasmen Depdiknas, 2003).

Teori

Pancasila adalah suatu ideologi dan dasar negara Indonesia yang menjadi landasan dari segala keputusan bangsa dan mencerminkan kepribadian bangsa Indonesia. Dengan kata lain, Pancasila adalah dasar dalam mengatur pemerintahan negara Indonesia yang mengutamakan semua komponen di seluruh wilayah Indonesia. Secara Etimologi, kata "Pancasila" berasal dari bahasa Sansekerta India (Kasta Brahmana), yaitu kata "Panca" yang artinya Lima, dan "Sila" yang artinya Dasar, sehingga arti Pancasila secara harfiah adalah Lima Dasar. Berikut ini adalah bunyi atau isi dari Pancasila, yakni sebagai berikut :

1. Ketuhanan Yang Maha Esa

2. Kemanusiaan yang Adil Dan Beradab

3. Persatuan Indonesia

4. Kerakyatan yang Dipimpin oleh Hikmat Kebijaksanaan Dalam

Permusyawaratan/Perwakilan

5. Keadilan Sosial bagi Seluruh Rakyat Indonesia

Secara harfiah karakter berarti "kualitas mental atau moral; kekuatan moral, nama atau reputasi" (Hidayatullah, 2010 : 9). Karakter adalah cara berpikir dan berperilaku yang menjadi ciri khas tiap individu untuk hidup dan bekerjasama, baik dalam lingkup keluarga, masyarakat, bangsa dan negara. Individu yang berkarakter baik adalah individu yang bisa membuat keputusan dan siap mempertanggungjawabkan setiap akibat dari keputusan yang ia buat (Suyanto, 2010).

Pendidikan karakter adalah suatu sistem penanaman nilai-nilai karakter kepada warga sekolah yang meliputi komponen pengetahuan, kesadaran atau kemauan, dan tindakan untuk melaksanakan nilai-nilai tersebut, baik terhadap Tuhan Yang Maha Esa (YME), diri sendiri, sesama, lingkungan, maupun kebangsaan sehingga menjadi 
manusia insan kamil. Dalam pendidikan karakter di sekolah, semua komponen (stakeholders) harus dilibatkan, termasuk komponen-komponen pendidikan itu sendiri, yaitu isi kurikulum, proses pembelajaran dan penilaian, kualitas hubungan, penanganan atau pengelolaan mata pelajaran, pengelolaan sekolah, pelaksanaan aktivitas atau kegiatan ko-kurikuler, pemberdayaan sarana prasarana, pembiayaan, dan ethos kerja seluruh warga dan lingkungan sekolah ( Sudrajat, 2010).

Pendidikan karakter adalah pendidikan budi pekerti plus, yang melibatkan aspek pengetahuan (cognitive), perasaan (feeling), dan tindakan (action). Menurut Lickona (2000), tanpa ketiga aspek ini, maka pendidikan karakter tidak akan efektif. Hal ini senada dengan pendapat Golemen (2000) yang menyatakan bahwa pendidikan karakter pada hakikatnya adalah pendidikan nilai yang melibatkan aspek pengetahuan (cognitive), perasaan (feeling), dan tindakan (action).

Dengan pendidikan karakter yang diterapkan secara sistematis dan berkelanjutan, seorang anak akan menjadi cerdas emosinya. Kecerdasan emosi ini adalah bekal penting dalam mempersiapkan anak menyongsong masa depan, karena seseorang akan lebih mudah dan berhasil menghadapi segala macam tantangan kehidupan, termasuk tantangan untuk berhasil secara akademis. Terdapat sembilan pilar karakter yang berasal dari nilai-nilai luhur universal, yaitu: pertama, karakter cinta Tuhan dan segenap ciptaan-Nya; kedua, kemandirian dan tanggungjawab; ketiga, kejujuran/amanah, diplomatis; keempat, hormat dan santun; kelima, dermawan, suka tolong-menolong dan gotong royong/kerjasama; keenam, percaya diri dan pekerja keras; ketujuh, kepemimpinan dan keadilan; kedelapan, baik dan rendah hati, dan; kesembilan, karakter toleransi, kedamaian, dan kesatuan (Suyanto , $2010: 1-3$ )

Pengertian Charakter Building dalam segi bahasa, Charakter Building atau membangun karakter terdiri dari 2 suku kata yaitu membangun (to build) dan karakter (character) artinya membangun yang mempunyai sifat memperbaiki, membina, mendirikan. Sedangkan karakter adalah tabiat, watak, aklak atau budi pekerti yang membedakan seserang dari yang lain. Dalam konteks pendidikan (Modul Diklat LAN RI, 2017) pengertian Membangun Karekter (character building) adalah suatu proses atau usaha yang dilakukan untuk membina, memperbaiki dan atau membentuk tabiat, watak, sifat kejiwaan, akhlak (budi pekerti), insan manusia (masyarakat) sehingga menunjukkan perangai dan tingkah laku yang baik berlandaskan nilai-nilai Pancasila.

Kesembilan pilar karakter itu, diajarkan secara sistematis dalam model pendidikan holistik menggunakan metode knowing the good, feeling the good, dan acting the good. Knowing the good bisa mudah diajarkan sebab pengetahuan bersifat kognitif saja. Setelah knowing the good harus ditumbuhkan feeling loving the good, yakni bagaimana merasakan dan mencintai kebajikan menjadi engine yang bisa membuat orang senantiasa mau berbuat sesuatu kebaikan. Lebih lanjut tumbuh kesadaran bahwa, orang mau melakukan perilaku kebajikan karena cinta dengan perilaku kebajikan tersebut. Setelah terbiasa melakukan kebajikan, maka acting the good itu berubah menjadi kebiasaan.

Berdasarkan grand design yang dikembangkan Kemendiknas (2010), secara psikologis dan sosial kultural pembentukan karakter dalam diri individu merupakan fungsi dari seluruh potensi individu manusia (kognitif, afektif, konatif, dan psikomotorik) dalam konteks interaksi sosial kultural (dalam keluarga, sekolah, dan masyarakat) dan berlangsung sepanjang hayat. Konfigurasi karakter dalam konteks totalitas proses psikologis dan sosial-kultural tersebut dapat dikelompokkan dalam: Olah Hati (Spiritual and emotional development), Olah Pikir (intellectual development), Olah Raga dan Kinestetik (Physical and kinestetic development), dan Olah Rasa dan Karsa (Affective and Creativity development) yang secara diagramatik dapat digambarkan sebagai berikut. 


\begin{tabular}{|c|c|}
\hline $\begin{array}{c}\text { Olah Pikir } \\
\text { Cerdas }\end{array}$ & $\begin{array}{c}\text { Olah Hati } \\
\text { Jujur, Bertanggung Jawan }\end{array}$ \\
\hline $\begin{array}{c}\text { Olah Raga dan Kinestetik } \\
\text { Bersih, Sehat, Menarik }\end{array}$ & $\begin{array}{c}\text { Olah Rasa dan Karsa } \\
\text { Peduli dan Kreatif }\end{array}$ \\
\hline
\end{tabular}

\section{METODE}

Metode penelitian adalah cara ilmiah yang dilakukan untuk mendapatkan data dengan tujuan tertentu. Metode/teknik penulisan makalah menggunakan studi pustaka. Pengertian studi pustaka adalah teknik pengumpulan data dengan melakukan penelaahan terhadap berbagai buku, literatur, catatan, serta bebagai laporan yang berkaitan dengan masalah yang dipecahkan.

\section{HASIL DAN PEMBAHASAN}

Pancasila sebagai dasar dan ideologi negara merupakan kesepakatan politik para founding fathers ketika negara Indonesia dididrikan. Pancasila mengandung nilainilai, yang memberikan dasar-dasar fundamental dan universal bagi kehidupan bermasyarakat, berbangsa dan bernegara. Dari lima sila tersebut, masing -masing memiliki nilai dan maknanya sendiri-sendiri.

Sila pertama: Ketuhanan Yang Maha Esa, yang mengandung nilai religious yang menjadi fondasi dalam kehidupan spiritual masyarakat Indonesia. Di saat pandemi Covid -19 penerapakan sila pertama dapat dilakukan dengan cara selalu berdoa dan berserah diri kepada Nya untuk keselamatan agar virus ini segera berakhir. Jadi sila pertama menjadi fundasi penguat dalam diri setiap insan pada masa pendemi ini. Sila kedua : Kemanusiaan Yang Adil dan Beradab, memiliki makna bahwa setiap orang wajib mengormati orang lain sesuai dengan harhat dan martabatnya, karena setiap orang dihadapan /di mata Tuhan adalah sama, sama sebagai makhluk Tuhan. Dengan ini diharapkan muncul rasa memanusiakan manusia, sehingga diharapkan bisa mencitai sesamanya seperti mencitani dirinya sendiri. Sikap ini menekankakn kita untuk memiliki rasa tenggang sara, menjununjung nilai kemanusiaan.

Sila ketiga : Persatuan Indonesia, yang memiliki makna bahwa masyarakat Indonesia harus bersatu padu, malaupun berbeda -beda dalam hal suku, ras, agama taupun kepercayaan. Dengan mengutamakan persatuan dan kesatuan apa yang dirasakan berat akan menjadi ringan, sebab ada pepatah mengatakan bahwa : "berat sangan dipikul dan ringan sama dijinjing". Lebih-lebih masa pandemi ini, kita harus bersatu padu untuk melawan corona, dengan tetap melakukan lima $M$, yakni : memakai masker, menjaga jarak, mencuci tangandengan air mengalir, menghindari berkumpul atau kerumunan, dan mengurangi aktivitas atau bepergian jika tidak penting.

Sila keempat : Kerakayataan yang Dipimpin oleh Hikamt Kebijaksanaan dalam Permusyawaratan/Perwakilan mengandung makna bahwa kepatuhan setiap negara kepada pemerintah menjadi langkah preventif dalam menghadapai pandemi Covid-19. Mendukung pemerintah untuk menerapakan Pembatalan Kegiatan Masyarakat Berskala Besar (PSBB) adalah satu cara untuk meminimalkan penyebaran Covid-19. Sila kelima : Keadilan Sosial bagi seluruh Rakyat Indonesia, memiliki makna pemerintah Indonesia harus berperikalu adil perihal social bagi seluruh rakyat. Dalam hal ini dibutuhkan kersama antara masyarakata, masyarakat dan pemerintah dalam menghadapai Covid-19.

Secara khusus Mantan Menteri Dalam Negeri, Tjahjo Kumolo (03-06-2020), terkait dengan nilai-nilai Pancasila menyatakan ada tiga nilai yang dirasakan sebagai blessing atau berkah dari penanganan pandemi Covid-19.

Pertama, nilai persatuan. Hal ini diwujudkan dalam kolaborasi yang cukup baik, cukup solid dari sissi pemerintah dan masyarakat dalam mencegah dan mengatasi penyebaran Covid -19. Manajemen penangangan Covid -19 juga cukup efektif dilaksanakan dari pusat sampai ke daerah. 
Kedua, nilai kemanusiaan. Nilai ini terlihat dari solideritas social seluruh elemen masyarakat yang bahu membau, tolong menolong membantu pelaksanaan tugas Satgas Covid -19 memupun membantu saudara sebangsa dan setanah air yang gterdapak pandemi Covid-19.

Ketiga, Keadilan sosial. Ketika pemerintah ingin menjaga keselamatan bangsa akibat pandemi Covid -19, pemerintah memikirkan bagaimana jaring pengaman sosialnya (JPS) nya. Pemerintah juga memikirkan bagaimana roda perekeonomian berjalan kembali sehingga kehidupan social-ekonomi bisa bersngsur pulih kembali.

\section{Penguatan Character Building}

Secara konseptual istilah pendidikan karakter ini sering disamakan dengan pendidikan nilai, pendidikan religius, pendidikan budi pekerti, pendidikan akhlak mulia, atau pendidikan moral (Samsuri, 2009: 1; Darmiyati Zuchdi, 2008: 5). Dalam kehidupan berbangsa, dan bernegara pendidikan karakter atau yang sering disebut dengan nation and character building senantiasa merupakan hal yang amat filosofis dan esensial dalam pembangunan manusia Indonesia seutuhnya. Pembangunan politik, sosial, ekonomi, hukum, keamanan, serta penguasaan IPTEKS hams menyatu dengan pembangunan karakter manusia sebagai pelaku dan penggunanya, sehingga tujuan pembangunan tersebut mencapai sasaran, yakni kesejahteraan, kemaslahatan dan kedamaian hidup umat manusia itu sendiri. Oleh karena itu, pendidikan karakter menjadi sangat penting dalam berbagai kegiatan pembangunan, dan secara khusus menjadi faktor dan perspektif yang sangat mendasar dalam kegiatan pembangunan di bidang pendidikan itu sendiri.

Oleh karena itu, pendidikan karakter perlu dikembangkan untuk membantu mengatasi kekurangan dan mengobati cacat fundamental tersebut. Pendidikan karakter, pendidikan moral, atau pendidikan budi pekerti itu dapat dikatakan sebagai proses untuk penyempumaan diri manusia, merupakan usaha manusia untuk menjadikan dirinya sebagai manusia yang berakhlak mulia, manusia yang berkeutamaan (Doni Koesoema , 2007: 81). Dikatakan manusia berkeutamaan maka pada diri manusia itu mengalir kebiasaan-kebiasaan atau perilaku baik sebagai hasil dari proses intemalisasi nilai-nilai utama, atau nilai-nilai positif seperti keyakinan kepada Sang Pencipta, jujur, saling menghormati antar sesama, peduli, sabar dan berlaku santun, percaya diri, tahan uji dan bermoral tinggi, tertib dan disiplin, demokratis dan bertanggung jawab dalam kehidupan bermasyarakat. Dengan demikian pendidikan karakter merupakan proses pembudayaan dan pemanusiaan.

Dengan pertimbangan dalam rangka mewujudkan bangsa yang berbudaya melalui penguatan nilai-nilai religius, jujur, toleran, disiplin, bekerja keras, kreatif, mandiri, demokratis, semangat kebangsaan, cinta tanah air, dan bertanggung jawab, pemerintah memandang perlu penguatan pendidikan karakter. Atas dasar pertimbangan tersebut, maka pada 6 September 2017, Presiden Joko Widodo telah menandatangani Peraturan Presiden (Perpres) Nomor: 87 Tahun 2017 tentang Penguatan Pendidikan Karakter.

Dalam Perpres ini disebutkan, Penguatan Pendidikan Karakter yang selanjutnya disingkat PPK adalah gerakan pendidikan di bawah tanggung jawab satuan pendidikan untuk memperkuat karakter peserta didik melalui harmonisasi olah hati, olah rasa, olah pikir, dan olah raga dengan pelibatan dan kerja sama antara satuan pendidikan, keluarga, dan masyarakat sebagai bagian dari Gerakan Nasional Revolusi Mental (GNRM).

Pendidikan karakter menjadi salah satu mandat yang harus dilaksanakan oleh Kemendikbud. Demi mencapai tujuan tersebut, Kemendikbud telah membuat kurikulum pendidikan yang berbasis Pancasila. Menurut Nadiem (5-6-2020) ada enam profil yang menjadi fokus pembinaan pendidikan karakter ini , keenam profil tersebut adalah sbb: (1) Berakhlak Mulia. Pelajar Pancasila haruslah berakhlak mulia. Akhlak mulia ini bisa dilihat dari moralitas yang terpancar dari setiap pribadi 
pelajar Pancasila. Pelajar Pancasila mengerti apa itu keadilan sosial, spiritualitas, punya rasa cinta kepada agama, manusia, dan cinta kepada alam.(2) Bernalar Kritis. Pelajar pancasila harus memiliki kemampuan bernalar kritis. Bernalar kritis adalah kemampuan beranalisa dan kemampuan memecahkan masalah-masalah yang nyata.(3) Kreatif. Pelajar Pancasila memiliki kemampuan bukan hanya memecahkan masalah, tetapi bisa menciptakan hal-baru, berinovasi secara mandiri, dan mempunyai rasa cinta terhadap kesenian dan budaya.(4) Kemandirian. Pelajar Pancasila harus memiliki jiwa yang mandiri, independent, termotivasi untuk meningkatkan kemampuannnya, mau bekerja keras karena ingin menjadi lebih baik. (5) Kebhinnekaan Global. Pelajar Pancasila memiliki profil kebinekaan global, yakni perasaan menghormati keberagaman, toleransi terhadap perbedaan di dunia internasional, dan (6) Gotong Royong. Pelajar Pancasila mempunyai kemampuan berkolaborasi , bergotong royong yang merupakan softskill utama yang terpenting terlebih di masa pendemi Covid-19. Untuk menghadapi pandemi Covid-19, memang dibutuhkan orang-orang yang berakhlak mulia, kritis, kreatif, mandiri, bergotong royong dan berwawasan global, sebab waba pandemi juga bersifat global, sehingga kita harus bergandengan tangan, bahu membahu, bergotong royong agar pandemi Covid -19 segera berakhir.

Dalam membangun karakter suatu bangsa diperlukan perilaku yang baik dalam rangka melaksanakan kegiatan berorganisasi, baik dalam organisasi pemerintahan maupun organisasi swasta dalam bermasyarakat. Maka karakter manusia merupakan suatu hal yang sangat penting untuk diperhatikan dalam rangka mewujudkan cita-cita dan perjuangan berbangsa dan bernegara guna terwujudnya masyarakat yang adil dan makmur berlandaskan Pancasila dan UUD 1945. Karakter adalah sesuatu yang sangat penting dalam pengembangan kualitas manusia maka karakter mempunyai makna sebuah nilai yang mendasar untuk mempengaruhi segenap pikiran, tindakan dan perbuatan setiap insan manusia dalam kehidupan bermasyarakat, berbangsa dan bernegara. Dalam hal ini adapun nilai-nilai dalam pembangunan karakter yang dimaksud adalah: (a) Kejuangan, (b) Semangat Kebersamaan atau Gotong Royong, (c) Kepedulian atau Solider, (d) Sopan Santun, (e) Persatuan dan Kesatuan, (f) Kekeluargaan, dan (g) Tanggung jawab. Dengan nilai-nilai Pancasila, berarti akan memperkuat Character Building, untuk mengahadapi permasalahan bangsa dan negara Indonesia yang sekarang ini sedang dilanda pandemi Covid-19.

\section{SIMPULAN}

Mengenalkan nilai-nilai luhur Pancasila sebagai The Way of Life, merupakan tanggung jawab dan tantangan kita bersama, khusunya di dunia pendidikan. Nilai-nilia tersebut harus dapat dikenalkan, ditanamkan dan dibiasakan sedini mungkin, melalui berbagai cara dengan karakter sosial budaya setempat. Pembiasaan tersebut untuk menjawab tantangan dalam mengajarkan, mendidik, mengasuh gererasi mula milineal agar menjadi generasi yang beradab, ber Bhinneka Tunggal Ika, dan be Pancasila terlebih pada masa pandemi Covid-19.

\section{DAFTAR PUSTAKA}

ALPTKI. (2009). Pemikiran Tentang Pendidikan Karakter Dalam Bingkai Utuh Pendidikan Nasional, Asosiasi Lembaga Pendidikan Tenaga Kependidikan. Jakarta : Demdiknas

Darmiyati Zuchdi. (2008). Humanisasi Pendidikan: Menemukan Kembali

Pendidikan Yang Manusiawi. Jakarta: Bumi Aksara.

Ditjen Dikdasmen Depdiknas. (2003). Undang-undang Republik Indonesia No. 20 Tahun 2003 Tentang Sistem Pendidikan Nasional.

Doni Koesoema A. (2007). Pendidikan Karakter, Jakarta: Grasindo.

Kemendiknas. (2010). Pembinaan Pendidikan Karakter di Sekolah Menengah Pertama. Jakarta. 
Lickona, Thomas. (2000). "Talks About Character Education", wawancara oleh Early Chilhood Today, ProQuest Education Journal, April, 2000.

Mendikbud Nadiem: Ini 6 Profil Pelajar Indonesia", : https://www.kompas.com/edu/read/2020/05/07/130140471/mendikbudnadiem-ini-6-profil-pelajar-indonesia, diakses, 1 Maret 2021

Peraturan Presiden (Perpres) Nomor: 87 Tahun 2017 tentang Penguatan Pendidikan Karakter.

Samsuri. (2009). "Mengapa Perlu Pendidikan Karakter", Makalah, disajikan pada workshop tentang Pendidikan Karakter oleh FISE UNY. Yogyakarta.

Soemamo Soedarsono. (2009). Karakter Mengantarkan Bangsa dari Gelab Menuju Terang. Jakarta: Kompas Gramedia.

Suyanto. (2010). Urgensi Pendidikan Karakter. Tersedia dalam http://www.mandikdasmen.depdiknas.go.id/web/pages/urgensi.html, diunduh $1-3-2021$

Tjahjo Kumolo. (2020) ."Aktualisasi Nilai-Nilai Pancasila Dalam Menangani Covid -19" .Makalah. Disampaikan pada Webinar Nasional Fakultas IImu Sosial UNES, 2 Juni 2020, diakses 5 Maret 2021 